\title{
A Visualization Method of Uneven Areas on Single Layer Thin Films
}

\author{
Toshiyuki Kashiwagi Member (Tokushima Prefectural Industrial Technology Center, kasi@itc.pref.tokushima.jp) \\ Shinji Higaki Non-member (Hamamatsu Metrix co., ltd., s_higaki@metrix.co.jp) \\ Toshiyuki Miyawaki Non-member (Hamamatsu Metrix co., ltd., miyawaki@metrix.co.jp) \\ Shunichiro Oe Member (Shikoku University, oe@keiei.shikoku-u.ac.jp)
}

Keywords : unevenness, visualization, thin film, frequency, interference, silicon wafer

\section{Introduction}

We propose a visualization method of uneven areas on single layer thin films formed on optical filters or semiconductor materials. High uniformity of the thickness of thin films is required to produce those devices, in spite of the difficulty of visual inspection. Our method visualizes uneven areas on thin films by detecting intensity variances of light interference. This method is based on the original techniques, which have been developed to detect non-uniform color areas using a color histogram.

\section{Capturing Method}

To capture images, we utilize a fluorescent lamp with 3 lighting spectrum peaks and a high sensitive color line sensor camera. Moreover, we adjust the proper capture angle to get the most sensitive intensity variances about 3 lighting spectra $(436 \mathrm{~nm}$, $546 \mathrm{~nm}$ and $610 \mathrm{~nm})$. Each lighting spectrum image is captured by $3 \mathrm{CCD}$ color sensors (blue, green and red) respectively. Fig.1 shows an image capturing method. In the taken color image, uneven areas of thickness of thin films are observed as uneven color areas.

\section{Detecting Uneven Areas in Color Images}

In previous work we have proposed a new feature image of which pixel holds the number of frequency of color vectors. This feature image that we call Frequency Image is made from a special color histogram of an image and presents a distribution of frequency of color. The frequency of the color of uneven areas is lower than that of normal areas in this Frequency Image. Therefore we can distinguish between uneven areas and normal areas using the frequency as a threshold.

\section{Visualization}

We propose two visualization ways using color and monochrome displays. Color visualization vector of $\boldsymbol{p}_{\boldsymbol{v}}$ is defined

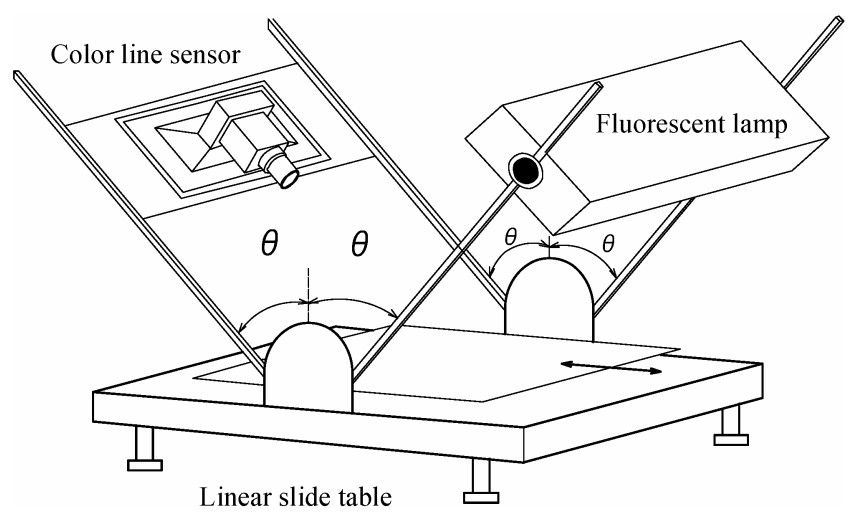

Fig. 1. Image capturing method by the following equation:

$$
\boldsymbol{p}_{\boldsymbol{v}}=\boldsymbol{p}_{\boldsymbol{o}}+k_{c}\left(\boldsymbol{p}-\boldsymbol{p}_{\boldsymbol{s}}\right)
$$

where $\boldsymbol{p}_{\boldsymbol{o}}$ is a standard vector of visualization, $\boldsymbol{p}$ is a color vector of each pixel, $\boldsymbol{p}_{\boldsymbol{s}}$ is an average vector of normal area pixels and $k_{c}$ is a positive emphasis constant. The normal area pixels, of which frequency is higher than the half of others, are selected in a frequency image. This color visualization method is effective to recognize a slight relative difference of thickness in uneven areas.

To understand the film thickness visually, we use a monochrome image in which the brighter pixel has the thicker thickness. We define the brightness $\mathrm{Y}$ of the pixel by following equation:

$$
Y=Y_{o}+k_{m}\left\|\boldsymbol{p}-\boldsymbol{p}_{s}\right\|
$$

where $\mathrm{Y}_{\mathrm{o}}$ is a standard brightness, $\left\|\boldsymbol{p}-\boldsymbol{p}_{\boldsymbol{s}}\right\|$ is an Euclidian distance between two vectors, and $k_{m}$ is an emphasis constant. The sign of $k_{m}$ is determined by the position of $\boldsymbol{p}$ in color space. If the $\boldsymbol{p}$ located at thicker thickness position compared to the $\boldsymbol{p}_{\boldsymbol{s}}$, the sign is plus. If not, the sign is minus.

\section{Experimental Results}

In our experiments to visualize uneven areas on a thin oxide layer on silicon wafers, we can discern the uneven area of which height has the difference of 2 nanometers from the normal area.

Fig. 2 shows the visualization result of uneven areas on a thin layer of silicon oxide by a monochrome image. In this image, the brighter pixel has the thicker thickness of the oxide layer.

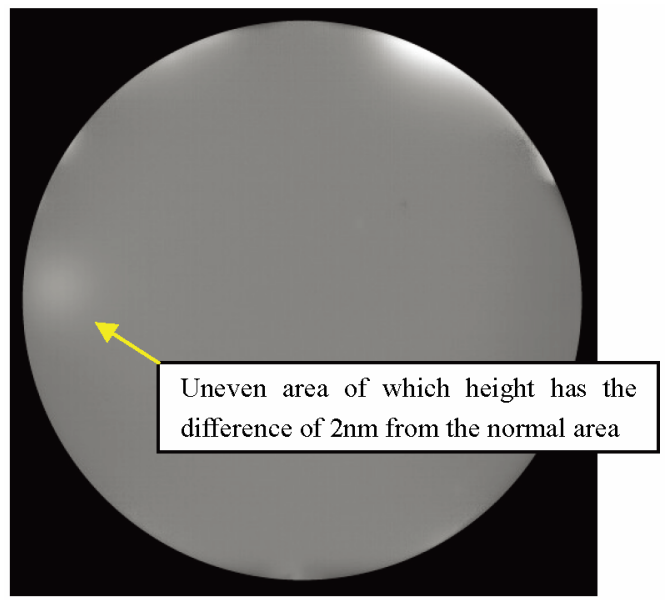

Fig. 2. Visualization result of uneen areas on a thin layer of silicon oxide by a monochrome image (film thickness:100nm) 


\title{
単層薄膜のむらの視覚化手法
}

\author{
正員 柏木 利幸* \\ 非会員 檜垣 真二** \\ 非会員 宮脇 俊幸** \\ 正 員 大恵俊一郎***
}

\author{
A Visualization Method of Uneven Areas on Single Layer Thin Films \\ Toshiyuki Kashiwagi*, Member, Shinji Higaki**, Non-member, Toshiyuki Miyawaki**, Non-member, \\ Shunichiro Oe ${ }^{* * *}$, Member
}

We propose a visualization method of uneven areas on single layer thin films formed on optical filters or semiconductor materials. High uniformity of the thickness of thin films is required to produce those devices, in spite of the difficulty of visual inspection. Our method visualizes uneven areas on the film by detecting intensity variances of light interference. To capture images, we utilize a fluorescent lamp with 3 lighting spectrum peaks and a high sensitive color line sensor camera. In the taken color image, uneven areas of thickness of thin films are observed as uneven color areas. Our method displays the uneven color areas based on the average vector of normal area pixels, which are selected by the original techniques to detect non-uniform color areas using color histogram. In our experiments to visualize uneven areas on a thin oxide layer on silicon wafers, we can discern the uneven area of which height has the difference of 2 nanometers from the normal area.

キーワード : むら, 視覚化, 薄膜, 頻度, 干渉, シリコンウェハ

Keywords : unevenness, visualization, thin film, frequency, interference, silicon wafer

\section{1. はじめに}

フィルタや平面ディスプレイ材料，半導体材料などに形 成された単層薄膜のむらの視覚化手法を提案する。これら の対象製品には膜厚の高い均一性が要求されるが，目視で の検査は極めて困難なものである。薄膜は，最近の薄型テ レビに用いられている液晶フィルタや半導体製造プロセス で形成されるシリコン酸化膜など, 種々の用途で利用され ており, 薄膜の持つ電気的な機能, 光学的な機能, 機械的 な機能などが最新のデバイスに高次元で利用されている。 これらの薄膜は，高精度な膜厚の管理技術が必要で，膜厚 に発生するむらは，薄膜の機能に重大な影響を及ぼしてい る。このため, 膜厚を計測するための種々の計測装置が開 発されてきた。

膜厚を計測する方法は，プローブによる接触方式，薄膜

\footnotetext{
* 徳島県立工業技術センター

干770-8021 徳島市雑賀町西開 11-2

Tokushima Prefectural Industrial Technology Center

11-2, Nishibari Saika-cho Tokushima-city, Tokushima 770-8021

** 浜松メトリックス（株）

干431-2103 静岡県浜松市北区新都田 1-4-10-10

Hamamatsu Metrix Co.Ltd.

1-4-10-10, Shinmiyakoda Kitaku Hamamatsu, Shizuoka 431-2103

*** 四国大学

干771-1192 徳島県徳島市応神町古川

Shikoku University

1-1-1, Hurukawa Ojin-cho Tokushima-city, Tokushima 771-1192
}

の光学的な特性を利用した非接触方式などがあり, 膜厚以 外の屈折率や吸収係数などの光学定数も計測できる光学方 式が高精度薄膜の評価に用いられている。代表的なものは, 検査光源の波長を連続的に変化させ，反射光のスペクトル の干渉強度の変化を調べる膜厚測定装置や偏光の偏波面に より異なる反射率，位相差を調べることにより計測を行う 偏光解析装置（エリプソメーター）などがある。しかし， これらは高精度であるがポイントもしくは小領域計測であ るため, 広範囲のむら計測には時間がかかり, インライン 検査には不向きである。このため, 生産現場では目視検査 が行われてきたが，これまでに目視検查に代わって，種々 の検査装置も考案されてきている。

生産現場で使用される検查装置は, 薄膜に照射した光の 表面と裏面での干渉による反射強度の変化をカメラで撮影 する方式のものが多く, 単色光源または狭帯域フィルタを 用いて, モノクロカメラで干涉の強度変化を画像として取 得している(1) (4)。また, 低反射膜を対象として膜厚差によ る色の分光反射特性の違いを利用するものもあり, カラー カメラを用いてカラー值 $(\mathrm{R}, \mathrm{G}, \mathrm{B})$ を取得し, R と B の色の 差分により検出を行っている(5)。このような画像取得方式に 関するこれまでの実例は特許文献の中に多く見られる ${ }^{(1) \sim(5)}$ 。

最近では数ナノメートル以下の膜厚差が問題となる微弱 むらがあり，熟練の検査員でも判別が難しく，これまで以 
上の検出感度を有する検査装置が望まれている。

本研究では微弱むらのインライン検查への前段階とし て, 検査角度を選択して微弱むらを感度良く検出し，視覚 化する手法を提案する。まず, 膜厚, 検査角度, 波長と干 渉強度の関係を説明し, 3 波長狭帯域光源とカラーラインセ ンサカメラを用いて最適な検出角度を設定して感度良くむ らの撮影を行う。3 波長それぞれの膜厚による干渉強度の変 化は色むらとして観察される。つぎに，取得したカラー画 像を用いて, 色の出現頻度を表す頻度画像を作成し, 頻度 画像を利用して検査対象物の均一領域を抽出する ${ }^{(6)}(8)$ 。さ らに, この均一領域を基準として, むらの強度分布の視覚 化を行う。視覚化はカラー画像と濃淡画像を利用する 2 つ の方法を考案した ${ }^{(9)}$ 。

これまでの研究では, 検出感度を上げるために, 膜厚に 応じて複数の検査波長を選択する報告はあるが(10)，本研究 のように, 固定の多波長を利用し, 検查膜厚に応じて検査 角度を最適に設定し, 微弱むらの強度分布を視覚化する報 告は無い。

本手法の対象とする膜厚は, 吸収のほとんど無い単層の 誘電体薄膜とし, 膜厚の変動幅は数十ナノメートル以下と する。シリコンウェハに形成された酸化膜 $100 \mathrm{~nm}$ と $1000 \mathrm{~nm}$ に対してむらの視覚化の実験を行ったところ, 計測值と似 かよったむらの強度分布を得ることができ，視覚的に微弱 むらを確認することができた。

\section{2. 撮像方法}

微弱な膜厚変化によるむらを検出するためには, 高精度 の撮像系が必要である。撮像系は，Fig.1 に示すように照明 と 12 ビット $2 \mathrm{k}$ 素子のカラーラインセンサカメラ, ワーク を搭載できる直線移動テーブル（スライダー）から構成さ れ，検査対象物に照射された入射光を正反射の位置で撮影 できる。照明は 3 波長の蛍光灯を使用しているため, カメ ラの RGB の帯域で 3 つ輝線スペクトル波長に対応寸る干 涉画像を取得することができる。すなわち，3 波長それぞれ の干渉画像は，カラーカメラでは色むらとして観測される。

照明とカメラの撮影角度は，むらが最も見やすい位置に 設定し, 検查対象物を移動させながらスライダーの位置に

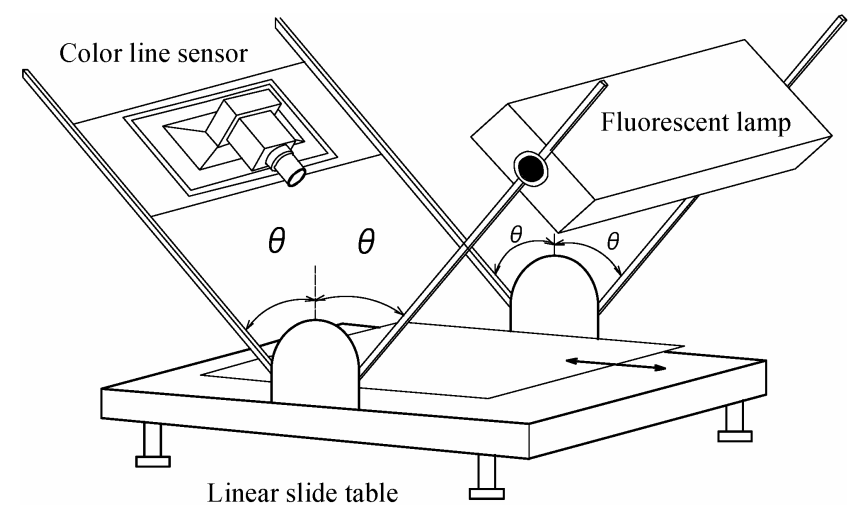

Fig. 1. Image capturing method.
同期してカラーラインセンサカメラで画像を取得する。な お，画像は無偏光の状態で取得し，撮像前には，標準のワ ークまたは白色板を使用して RGB 独立にシェーディング補 正を実施している。

\section{3. 原理}

膜厚むらは，カラーカメラにより色むらとして観測され る。本章では, 微弱な膜厚むらをどのようにして色むらと して取得するか, また, 取得した色むらをどのように視覚 化するかを説明する。

〈3・1〉膜厚むらと干渉 反射方式で薄膜を撮影する と, 膜厚により明暗が観察される。また撮影する角度を変 えても明暗が変化する。明暗は主に薄膜の表面で反射され た光と董面で反射された光が干渉することにより発生す る。今, Fig.2のように基板の上に薄膜がある場合を考える。 空気, 薄膜, 基板の屈折率を $n_{1}, n_{2}, n_{3}\left(n_{1}<n_{2}<n_{3}\right)$ とすると, 薄膜の表面の境界では, スネルの法則が成り立つから表面 の入射角を $\theta_{1}$, 屈折角（透過角）を $\theta_{2}$ として, 次式の関係 が成り立つ。

$$
n_{1} \sin \theta_{1}=n_{2} \sin \theta_{2}
$$

膜厚を $t$ として光路差 $l$ は $\left(2 n_{2} \overline{P R}-n_{1} \overline{P Q}\right)$ であるから

$$
l=2 t n_{2} \cos \theta_{2}=2 t \sqrt{n_{2}^{2}-n_{1}^{2} \sin ^{2} \theta_{1}}
$$

となる。ところで，二つの波の振幅を $A_{1}, A_{2}$, 二つの波 の位相差を $\alpha$ とすると合成された波の振幅 $A_{0}$ の 2 乗は

$$
A_{0}^{2}=A_{1}^{2}+A_{2}^{2}+2 A_{1} A_{2} \cos \alpha
$$

と表される。この式の右辺の 1,2 項は定数項で，第 3 項 が干渉項となる。CCD で観測される光の強度は振幅の 2 乗 に比例するための, ( 3 )式に比例した強度が観測され, その 変動分は干渉項に比例する。

本手法の視覚化対象としている数十ナノメートル以下の 膜厚変動範囲では， $\alpha$ が $2 \pi$ の整数倍のとき位相が重なって 最も明るく見える。これは, 点 $\mathrm{P}$ と点 $\mathrm{R}$ における反射波の 位相変化が等しいとすると, 光路差が波長の整数倍のとき である。光路差 $l$ と $\alpha$ は, 波長を入として,

$$
\alpha=\frac{2 \pi l}{\lambda}-\phi=\frac{4 \pi n_{2} \cos \theta_{2}}{\lambda} t-\phi
$$

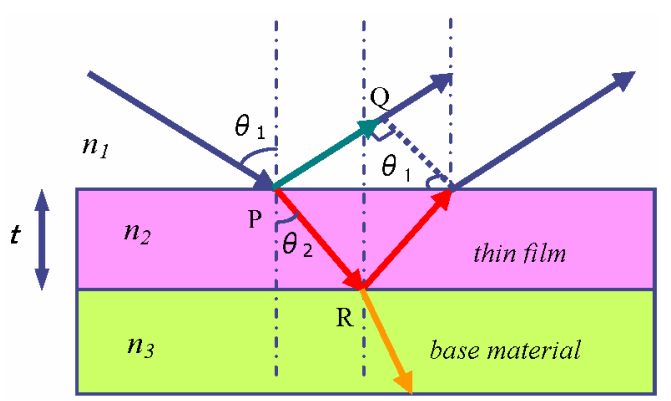

Fig. 2. Optical path of incident light at uniform planar interfaces of a thin film. 
の関係がある。ここで， $\phi$ は点 $\mathrm{P}$ と点 $\mathrm{R}$ における反射波 の位相変化による初期位相差で, 基板が誘電体の場合, $n_{1}<n_{2}<n_{3}$ では $\phi=0, n_{1}<n_{2}>n_{3}$ では $\phi=\pi$ となる。また, 基板 が誘電体でない場合は， $\phi$ は基板の複素屈折率に基づいた 值となり計算により求めることができる。波長と入射角が 固定の場合, $\alpha$ は膜厚 $t$ の一次関数となる。

〈3·2〉 最適撮影角度の設定 数ナノ程度の膜厚の微 少変化を捉えるために, 膜厚の微少変動で, 明るさ変化率 ができるだけ大きくなる撮影角度に設定する。

画像取得時には, 波長, 角度などの条件は固定であるた め, $(4)$ 式より, 膜厚 $t$ の変動は, 位相差 $\alpha$ の変動となる。 このとき，(3)式を $\alpha$ で微分すると，入射波と反射波の振幅 は定数であるため, 合成波の振幅の 2 乗 $\left(A_{0}{ }^{2}\right)$ の変化率, 寸 なわち明るさの変化率は,

$$
\frac{d}{d \alpha} A_{0}^{2}=-2 A_{1} A_{2} \sin \alpha
$$

となる。したがって, $\alpha$ が $\pi / 2$ または $3 \pi / 2$ 付近のとき, すなわち $\cos \alpha=0$ 付近で, 膜厚の微少変動による明るさの変 化量が大きい。

屈折率と薄膜の膜厚設計值が予め分かっている場合に は, $\cos \alpha=0$ となるように $\theta_{2}$ すなわち $\theta_{1}$ を調整してむらの 変動が最も良く観察できる角度に設定することができる。 また，(4)式より $\theta_{2}$ が小さいほど膜厚による明暗の周期は 短くなり, 膜厚の微弱変動に対する感度も上がると考えら れるためできるだけ小さな $\theta_{1}$ を選択する。

本手法では, カラーラインセンサカメラで 3 波長の干渉 画像を同時に取得するが, 3 波長とも感度の高い角度に設定 し難い場合がある。しかし，2波長程度であれば比較的簡単 に感度の高い角度に設定できる。具体的な $\theta_{1}$ の求め方は次 章にて説明する。

以上の原理は，薄膜の表面と裏面の反射の干渉だけに着 目し，薄膜の表面と裹面間で生じる多重繰り返し反射によ る干渉の影響は少ないと考えている。

$\langle 3 \cdot 3\rangle$ むらの可視化手順 可視化は, 3 波長の干渉画 像をカラー画像として取得し, 色の出現頻度を表す頻度画 像を作成した後に，均一領域を抽出する。さらに，この領 域を基準として, 各画素との空間的な距離を求めることに より行う。手順を以下に説明する。

(1) 干渉画像の取得

カラーラインセンサカメラで取得できる画像は, 12 ビッ トの画像であるが, 12 ビットのカラー画像からカラーヒス トグラム空間を構成すると, 大きなメモリ空間が必要とな り，メモリの使用効率も良くない。そこで，まず，ノイズ の影響を避けるため上位 10 ビットを利用して, 3 波長 10 ビ ットの干渉画像を取得する。さらに, この 10 ビット画像に おいて, 各カラー值の変動部分のみを切り出し 8 ビットの カラー画像とする。切り出しは RGB 独立に行う。具体的に は, 正常ワークを撮影し, カラーデータの濃度断面である 3 つのラインプロファイルを得て, このラインプロファイル の平坦部分に近い水平ラインを切り出しの基準として, そ
の上下の 7 ビット分に相当するデータを RGB 独立に取得し ている。基準は厳密なものでなくても良いためマニュアル で設定しており, ワークの種類を変更しない限り切り出し 基準の変更を行う必要はない。切り出した部分は, (3)式に おける干渉項の変化部分を強調して取り出したカラー画像 に相当する。以後, この 8 ビットカラー画像を用いて可視 化処理を行う。

（2）頻度画像の作成

頻度画像は，頻度情報を有するカラーヒストグラム空間 を利用して作成する(7)。

カラー画像を, 座標を表す $2 つ$ 独立変数 $x, y$ の関数 $f(x, y)$ によって表現し, $f(x, y)$ をカラーヒストグラム空間上にプロ ットしたものを $\boldsymbol{H}$ とする。 $\boldsymbol{H}$ は R, G, B それぞれの座標の成 分とその座標における頻度を保持している。

元の画像 $f(x, y)$ のカラー值を $\boldsymbol{H}$ より得られる頻度に置き 換えると $f(x, y)$ は, カラー值の出現頻度を表す濃淡画像と なる。この画像を頻度画像 $g(x, y)$ と呼ぶ。

均一性の高い検査対象物に対しては, 頻度画像の頻度の 高い部分は均一部で, 頻度の低い部分は不均一部分とな る ${ }^{(6) \sim(8)}$ 。頻度画像は複数枚使用することで高いノイズ除去 能力が期待できる。

(3) 基準ベクトル検出

RGB 空間における基準ベクトルを検査対象物の均一エリ アの平均ベクトルと定義しこれを $\boldsymbol{p}_{\boldsymbol{s}}$ とおく。しかしながら， 検查対象物のどこが均一エリアかを特定することは難し く, 一般的な方法では $\boldsymbol{p}_{\boldsymbol{s}}$ を求めることは困難である。そこ で, 頻度画像を利用して $p_{s}$ を求める。まず, このような検 査対象物では均一部分は少なくとも検査対象エリアの $50 \%$ 以上はあると考えて, 頻度画像において頻度の高い画素か ら順に検查エリアの $50 \%$ に相当する画素数までを抽出す る。その後, 抽出したそれらの画素の平均ベクトルを求め, これを基準ベクトル $\boldsymbol{p}_{\boldsymbol{s}}$ とする。これにより不均一部分を平 均值計算から除去でき, 均一エリアの信頼性の高い平均べ クトルを取得することができる。

(4) むらのカラー表示

カラー值として取得された干渉画像の各画素のカラーベ クトルを $\boldsymbol{p}$, 可視化基準とするカラーベクトルを $\boldsymbol{p}_{\boldsymbol{o}}$ とし, 表示のためのベクトル $\boldsymbol{p}_{\boldsymbol{v}}$ を次式で定義する。

$$
\boldsymbol{p}_{\boldsymbol{v}}=\boldsymbol{p}_{\boldsymbol{o}}+k_{c}\left(\boldsymbol{p}-\boldsymbol{p}_{\boldsymbol{s}}\right)
$$

ただし， $k_{c}$ は正の定数

本論文での実験には， $\boldsymbol{p}_{\boldsymbol{o}}=(127,127,127)$ を使用した。

微弱なむらの場合, $\boldsymbol{p}_{\boldsymbol{s}}$ と $\boldsymbol{p}$ は, 近い位置にあるため可視化 のためには大きめの $k_{c}$ の值を設定してむらの強度差を強調 する必要がある。本カラー表示方法は微弱な膜厚差の視認 に適している。

（5）むらの強度による濃淡表示

前述のカラー表示方法では, 検查角度により膜厚変動に 対応する色変動が異なっている。このため, 色変化がどの ように膜厚変化に対応しているか事前知識が無いと分から 


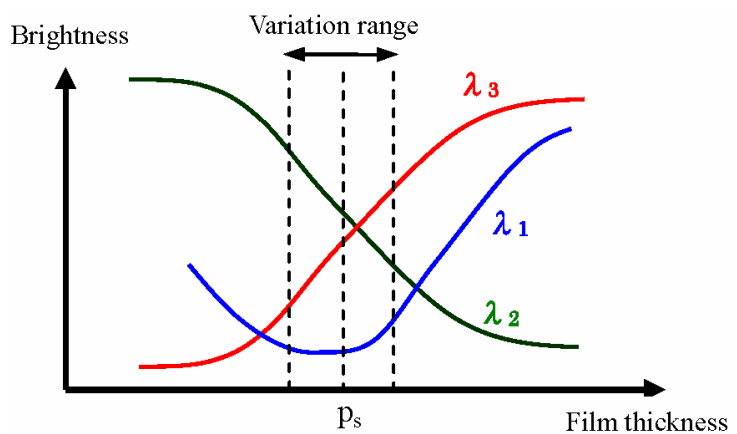

Fig. 3. Brightness variations by thickness of a thin film at different wavelengths.

ず，膜厚を視認するには不都合な場合がある。そこで膜厚 の厚さに応じて濃淡で表示する方法を提案する。

干渉画像の明るさ変動は $\cos \alpha$ に比例するため, 膜厚が増 加する時に明るさが増える場合と，その逆の場合がある。 これは，使用する波長によっても変わる。

Fig.3 に異なった波長と膜厚による干渉画像の明るさの変 動例を示している。膜厚むらによる膜厚変動幅の範囲では, 膜厚が増えると, 波長 $\lambda_{3}$ では明るさが増え（単調増加）, $\lambda_{2}$ では明るさが減る(単調減少)。また， $\lambda_{1}$ では明るさが あまり変動していない。むらの強度を濃淡表示するために は, Fig.3の $\boldsymbol{p}_{\boldsymbol{s}}$ を基準として $\boldsymbol{p}_{\boldsymbol{s}}$ より右側では膜厚が厚くなる ほど明るく，左側では膜厚が薄くなるほど暗く表示すると 直感的に分かりやすい。基準の明るさを $Y_{0}$ として, 表示す る画素の明るさYを次式で定義する。

$$
Y=Y_{o}+k_{m}\left\|\boldsymbol{p}-\boldsymbol{p}_{s}\right\|
$$

ここで， $k_{m}$ は定数で，Fig.3で $\boldsymbol{p}$ の值が $\boldsymbol{p}_{\boldsymbol{s}}$ より左側にある 場合が負，右側にある場合が正の值とする。なお， $\left\|\boldsymbol{p}-\boldsymbol{p}_{\boldsymbol{s}}\right\|$ は，二つのベクトル間のユークリッド距離を表すが，Fig.3 の $\lambda_{1}$ のように, 膜厚変動幅内で明るさの変動がほとんどな い成分に関しては，その成分を除いて計算を行うものとす る。本論文での実験には $\mathrm{Y}_{\mathrm{o}}=127$ を使用した。

\section{4. 実験と考察}

直径 $20 \mathrm{~cm}$ のシリコンウェハ上に形成された，膜厚約 $100 \mathrm{~nm}$ と $1000 \mathrm{~nm}$ の 2 種類の単層シリコン酸化膜について, その膜厚むらを可視化する実験を行った。使用した蛍光灯 の輝線のピーク波長は, 436nm (青), 546nm (緑), 610nm (赤) である。

$\langle 4 \cdot 1\rangle$ 撮影角度の検討 空気の屈折率 $n_{1}=1.0$, シリコ ン酸化膜の屈折率 $n_{2}=1.47$, 初期位相差 $\phi=0$, 膜厚 $t=100 \mathrm{~nm}$ または $t=1000 \mathrm{~nm}$ として, 撮影角度の検討を行った。各検查 波長に対して，入射角度 $\theta_{1}$ を変化させたときの $(3)$ 式にお ける干渉項の $\cos \alpha$ を, (2)式と(4)式を用いて次式により計 算する。

$$
\cos \alpha=\cos \left(\frac{4 \pi t}{\lambda} \sqrt{n_{2}^{2}-n_{1}^{2} \sin ^{2} \theta_{1}}-\phi\right)
$$

この值が 0 に近いとき膜厚変動に対して最も明度変化が

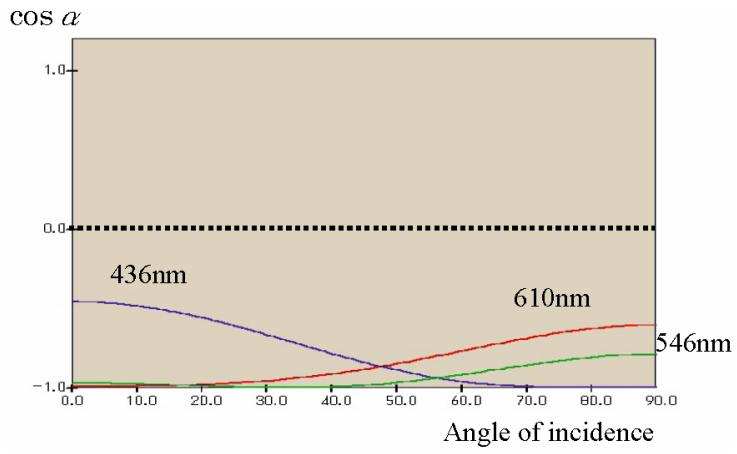

Fig. 4. The variance of $\cos \alpha$ in the interference term. (Film thickness:100nm)

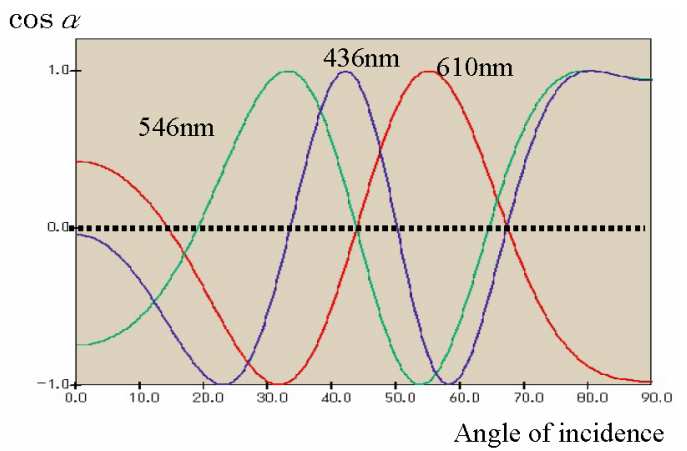

Fig. 5. The variance of $\cos \alpha$ in the interference term. (Film thickness:1000nm)

大きく感度が高い。Fig.4 と Fig.5 に膜厚が 100nm と 1000nm の各検査波長の $\cos \alpha$ の変動を示す。これらの図において, 入射角度が小さく $\cos \alpha=0$ のラインに 3 波長とも近い角度 を選択できれば膜厚変動を感度良く検出できる。

しかし，膜厚 $100 \mathrm{~nm}$ では，どの波長もあまり感度が良く ない。これは, $100 \mathrm{~nm}$ の光学膜厚が可視光の中心である緑 の波長の $1 / 4$ 波長に相当し, 反射防止膜として機能している ためと考えられる。このため, 長波長側と短波長側で膜厚 変動に対する感度がやや良くなっている。

また, 膜厚 $1000 \mathrm{~nm}$ では, 20 度と 45 度付近で, 赤と緑の 波長の感度が良いが青の波長は悪くなる。一方, 35 度付近 では青の感度が良いが，緑と赤は悪くなる。

以上より，入射角すなわち撮影角度を 20 度として実験を 行った。

ところで，繰り返し多重反射の干渉を考慮した薄膜の反 射率はフレネル係数を利用して求めることができる ${ }^{(11)}$ 。実 験に使用した各波長で，入射角を 20 度として，100nm およ び $1000 \mathrm{~nm}$ 付近の反射率の計算結果を Fig.6 と Fig.7 に示す。

膜厚 $100 \mathrm{~nm}$ では青の感度が良く, 100nm 近傍で単調増加, 膜厚 $1000 \mathrm{~nm}$ では, 赤と緑の感度が良く, $1000 \mathrm{~nm}$ 近傍で赤 は単調増加, 緑は単調減少であることが分かる。

〈4·2〉実験結果シリコンウェハに形成された酸化 膜 $100 \mathrm{~nm}$ と $1000 \mathrm{~nm}$ に対してむらの視覚化を行った。 


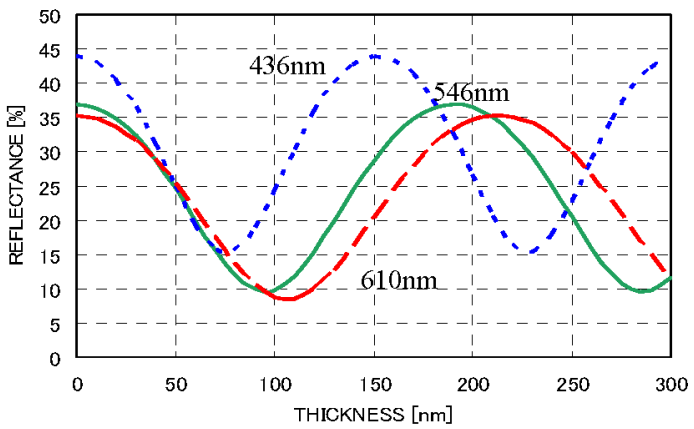

Fig. 6. Thickness and reflectance of interference. (Angle of incidence:20deg)

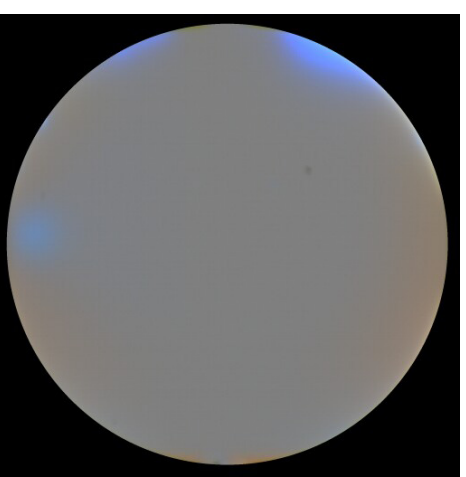

Fig. 8. Visualization result of uneven areas on a thin layer of silicon oxide by a color image. $\left(k_{c}=3\right.$, Film thickness: $\left.100 \mathrm{~nm}\right)$

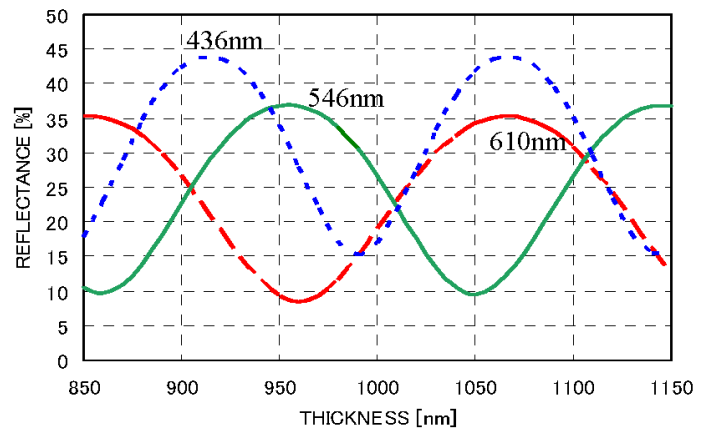

Fig. 7. Thickness and reflectance of interference.

(Angle of incidence:20deg)

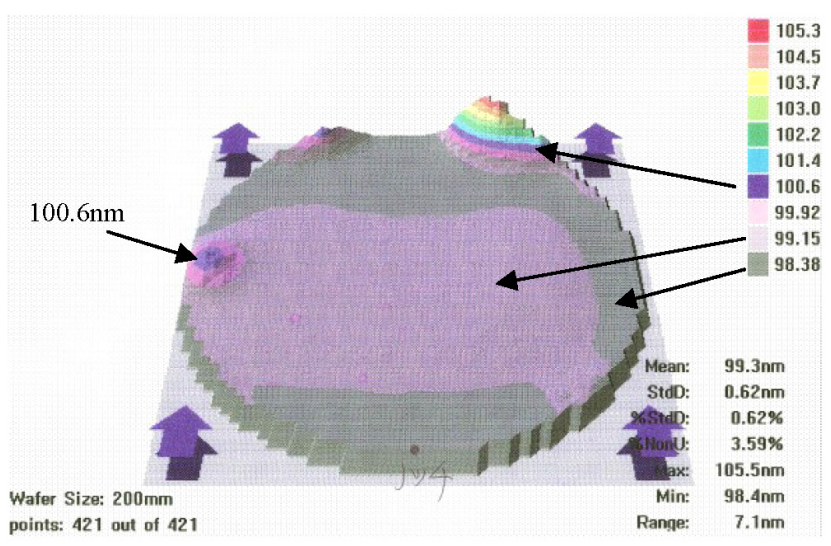

Fig. 11. Measurement result of the sample of Fig.8 using an optical thin film measurement system.

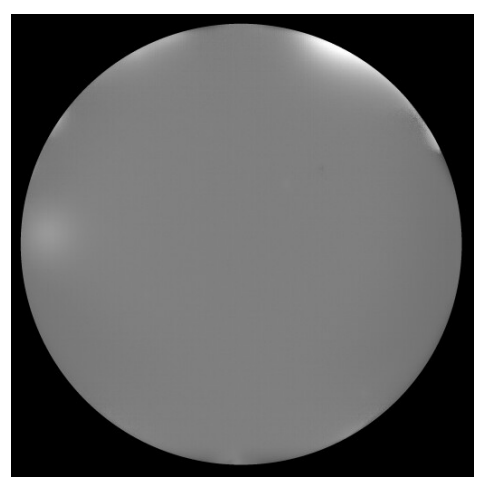

Fig. 9. Visualization result of uneven areas on a thin layer of silicon oxide by a monochrome image. $\left(k_{m}=1.5\right.$, Film thickness:100nm)

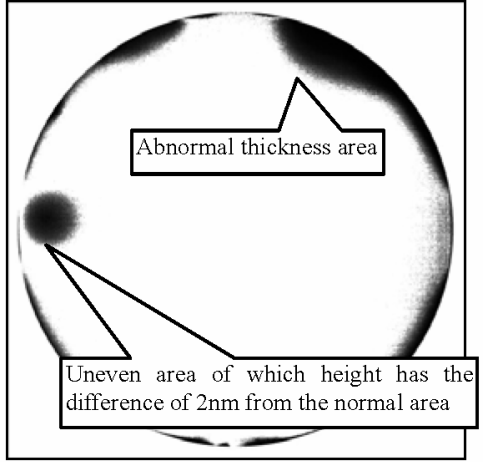

Fig. 10. Frequency image of the sample of Fig.8. (Film thickness: 100nm)
(1) 酸化膜 $100 \mathrm{~nm}$

Fig.8 に，右上部に膜厚異常箇所のあるサンプルを(6)式 によりカラー表示した結果を示す。また, Fig.9 には, 同じ サンプルを( 7 )式により膜厚が厚いほど明るくなるように 表示した結果を示す。この時, 青の波長を単調増加, 赤の 波長を単調減少とし, 緑の波長は使用していない。Fig.8 と Fig.9 を比べると, カラー表示では微少な膜厚差がよく分か るのに対して，モノクロ表示では膜厚の分布状況が直観的 に視認し易い。

さらに, Fig.10には, 同じサンプルの 8 ビットカラー画像 より作成した頻度画像を示している。実測では, 膜厚異常 箇所である図中の右上部が正常部分より $6 \mathrm{~nm}$ 程度厚く, 左 エッジ付近の丸い部分は $2 \mathrm{~nm}$ 程度厚くなっている。頻度画

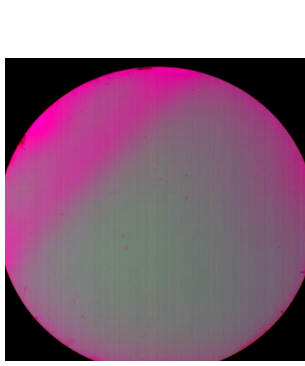

(a) Visualization result of NG sample by a color Image ( $\left.k_{c}=1.2\right)$

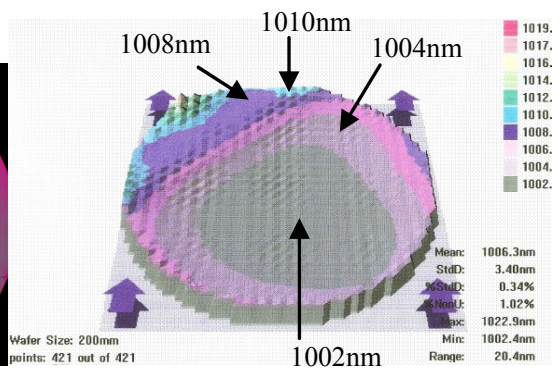

(b) Measurement result of NG sample of (a)

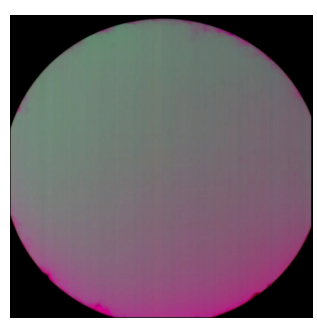

(c) Visualization result of OK sample by a color Image $\left(k_{c}=1.2\right)$

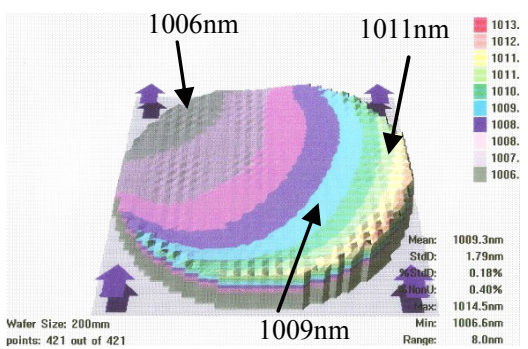

(d) Measurement result of OK sample of (c)

Fig. 12. Comparison with visualization results and measurement results. (Film thickness:1000nm) 
像では，むらの位置は特定できるもののむらの強弱までは 視認できない。一方，本手法による表示結果では，むらの 強弱まで視認できる。

光学式の計測器を用いて, このサンプル 400 ポイント余 りの箇所について膜厚を計測した結果を Fig.11 に示す。 Fig.11 で膜厚が厚い部分は, Fig.9 では明るく表示されてい ることが分かる。

(2) 酸化膜 $1000 \mathrm{~nm}$

膜厚 $1000 \mathrm{~nm}$ のむらの微弱変化は, 100nm のむらよりも感 度良く検出できる。Fig.12 に, 膜厚異常箇所のあるサンプル と正常サンプルについて, (6)式による視覚化の結果と実測 の結果を比較して示す。カラー表示では赤と青の波長は単 調増加, 緑の波長は単調減少として表示されている。

〈4·3〉 考 察 むらを見やすくするための視覚化 係数 $k_{c}, k_{m}$ と, 実測結果による膜厚とむらの強度の関係, 基準ベクトル，感度，光源，課題について検討する。

(1) 視覚化係数

(6), (7)式で用いる視覚化のための係数 $k_{c}, k_{m}$ は, 対象 ワークのむらを判別できるように知覚的に決定される。本 実験のように 12 ビットのカメラを用いる場合, 取得画像の 上位 8 ビット表示画像に比べて, $k_{c}=1$ では原画像の特定の レベルの変化分を 16 倍に, $k_{c}=2$ では 32 倍に拡大して観測 していることになる。 $k_{m}$ に関しては 3 変数の変化量をユー クリッド距離として計算しているため， $k_{c}$ のさらに $1 \sim 1.73$ 倍程度になる。本実験では，視覚化した画像における久陥 部分が表示レベルの最大值を超えないような值に設定して いる。

\section{(2) むらの強度と膜厚}

むらの強度と膜厚変動の視覚的な一致度を調べるため に, 計測結果のマップを参考に, むらのモノクロ表示画像 に等輝度線を追加した。この画像を Fig.13 に示す。なお, 緩やかに輝度が変化している部分は，ノイズなどにより境 界線が不安定になるため，モノクロ表示画像にはメディア ンフィルタを適用している。Fig.13(a)は，Fig.9 に等輝度線 を付加したもの, Fig.13(b),(c)は, Fig12(a),(c)に対応するモノ クロ表示画像にそれぞれ等輝度線を付加したもの, Fig.13(d) は，基準ベクトルを RGB の平均值として，モノクロ表示画 像を作成後, Fig.13(b)と同じ輝度レンジで等輝度線を付加し

たもである。

Fig.12(c)および Fig.13(c)とこれに対応する計測結果 Fig.12(d)を比べると, 膜厚の変化が緩やかなところではずれ が生じている。これはシェーディング補正が膜厚差 $1 \mathrm{~nm}$ 以 下のレベルまで厳密に行えていないのが原因であると推測 している。一方，膜厚変化の大きな箇所では視覚的によく 一致している。本研究の目的は, 熟練の検査員でも判別が 難しいような微弱むらの視覚化である。このようなむらは， 局所的に膜厚差があり, シェーディング補正が不十分であ っても視覚化された画像では視認できるため,ずれは実質 的には問題とならないレベルであると考えている。

(3) 基準ベクトル

本手法は基準ベクトルの検出に頻度画像を利用している ことを特徴としている。Fig.13 の(b)と(d)を比較すると, 部 分的に等輝度線の閒隔が変わっている箇所が見られる。こ のように，基準ベクトルとして単に RGB の平均を使用した 場合には，サンプルごとに正常部分のレベルが変動するだ けでなく部分的に輝度変化率が変わる場合もある。

(4) 感度

検出感度に関しては, ( 3 )式において, 干渉項と定数項の 比 $2 A_{1} A_{2} /\left(A_{1}{ }^{2}+A_{2}{ }^{2}\right)$ も考慮する必要がある。この比はフレネ ルの式(11)より計算可能で, 比の值が大きいほど感度が良い。 本実験サンプルの場合, 比の值は 0〜40 度の範囲で差異は あまり見られず，感度の向上はあまり期待できない。

(5) 光 源

本実験ではアパーチャ付きの 3 波長の蛍光灯を使用して おり, 輝線部分のレベルは高く狭帯域で干渉現象の観察に は適していると考えている。しかし，輝線以外の波長では， レベルはかなり低いものの広帯域の発光波長領域もあり感 度を低下させる要因になっていると考えられる。

(6) 課題

本手法は，3波長を利用し，対象ワークが代わっても，検 查角度の変更だけで, 高感度に膜厚の変動分を捉えること を特長としている。膜厚の微少変化が明るさのリニアな変 動として高感度に検出できる角度を選択しているが，実測 值との㛜密な相関は十分に検討していない。また，対象ワ 一クの基準膜厚とその变動幅が分かれば, Fig.6, 7 のような 3 波長の反射率の変化から膜厚と明るさのある程度の線形

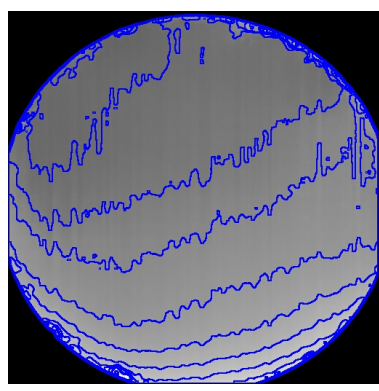

(c) Contour map of OK sample in Fig. 12

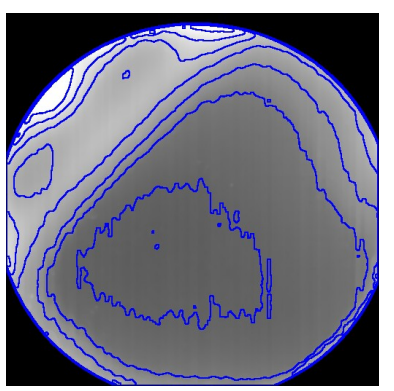

(d) Contour map of NG sample in Fig. 12 using an RGB average vector as a standard vector

Fig. 13. Contour map based on the mura (uneven area) intensity. ((a): $k_{m}=1.5$, (b)-(d): $k_{m}=1.2$ ) 
性を推定できるが，対象ワークを特定できない状況では推 定が難しい。

本手法が，膜厚の計測に利用できるかどうかの検討は今 後の課題である。

\section{5. まとめ}

3 波長蛍光灯による 3 波長それぞれの干渉画像を, 撮影角 度を調整することにより, 感度良くカラー画像として取得 する方法を説明した。3 波長それぞれの膜厚による干渉強度 の変化は，色むらとして観察される。さらに，このむらを 可視化する方法として, 頻度画像を利用して, 検査対象物 の均一領域を求め, 均一領域を基準として, むらの強弱を カラー画像で表示する方法と, むらの強度に合わせて濃淡 表示する方法を提案した。シリコンウェハ上に形成された 単層シリコン酸化膜のむらを視覚化したところ, 実測值と 視覚的に似かよった分布を得ることができた。また，2nm 程度の高低差のあるむらを視認することが可能であった。 実測に用いたシリコンウェハの膜厚計測器は，ポイント計 測であるため, 10 分以上の計測時間を要するが，本手法で は 30 秒程度の画像の取込時間で視覚化を行うことができ る。

本手法は，薄膜に限定されず，一般的な色むらの可視化 にも有効である。本技術を応用したむらのオフラインの検 査装置は既に実用化されており，薄膜に限らず幅広い用途 に対応できる仕様となっている。

本研究は，関東経済産業局の委託により平成 16,17 年度 地域新生コンソーシアム研究開発事業「高精度な液晶色ム ラ検査システムの開発」として実施した研究に基づいて改 良研究を行ってきた成果である。ご支援をいただいた関係 機関の方々に深く感謝いたします。

(平成 21 年 12 月 10 日受付，平成 22 年 3 月 28 日再受付)

\section{文献}

（1）「透明膜の検査方法」: 特開平 10-38753

(2)「膜厚么ラ検査方法」: 特開平 2007-114125

(3)「着色膜厚ムラ検査方法および装置」: 特開平 2007-205743

（4）「反射防止フィルムの反射防止層の膜厚を測定する方法」: 特開平 $2007-10403$

（5）「膜厚むら検査装置, 膜厚むら検査方法および膜厚むら検査プログラ 厶」: 特開平 $2003-166941 \mathrm{~A}$

(6) T. Kashiwagi and S. Oe : "An Evaluation Method of Color Uniformity", VIEW2002, Vol.14, pp.73-78 (2002) (in Japanese) 柏木利幸・大恵俊一郎：「色の均一性評価手法」, 第 14 回外観検査の 自動化ワークショップ講演論文集，pp.73-78 (2002)

( 7 ) T. Kashiwagi and S. Oe : "A Detection Method of Non-uniform Color Area Using Color Histogram”, Trans. IEEJ, Vol.124-C, No.3, pp.666-671 (2004-3) (in Japanese)

柏木利幸・大恵俊一郎：「カラーヒストグラムを用いた色の不均一部 分検出手法」, 電学論 C, 124, 3, pp.666-671 (2004-3)

(8) T. Kashiwagi and S. Oe : "Detection Technique of Color Unevenness", Proc. of the 2003 Japan Industry Applications Society Conference, Vol.2, 2-S17-4, pp.285-290 (2003) (in Japanese)

柏木利幸・大恵俊一郎：「色むら検出法」, 平成 15 電学産業部大講演 論文集 [II ] , 2-S17-4, pp.285-290 (2003-8-26〜28)

(9) T. Kashiwagi, S. Higaki, T. Miyawaki, and S. Oe : "A Visualization Method of Uneven Areas on Thin Films", Proc. of Electronics, Information and Systems Conference Electronics, Information and System Society, IEEJ, TC8-4, pp.195-200 (2009) (in Japanese)

柏木利幸・檜垣真二 ・宮脇俊幸・大恵俊一郎：「薄膜のむらの視覚化 手法」, 平成 21 電学電子・情報・システム部大講演論文集, TC8-4, pp.195-200 (2009)

(10) K. Taniguchi, K. Ueta, H. Onishi, and S. Tatsumi : "A detection method of mura on a thin layer using interference light”, IEE J, IIS06022, pp.17-22 (2006) (in Japanese)

谷口和隆・上田邦夫・大西浩之・辰巳昭治 :「干渉光を用いた薄膜の ムラ検出手法」, 電学産業システム情報化研, IIS06022, pp.17-22 (2006)

（11）小檜山光信：「光学薄膜の基礎理論」，（株）オプトロニクス社発行 (2003-7-23)

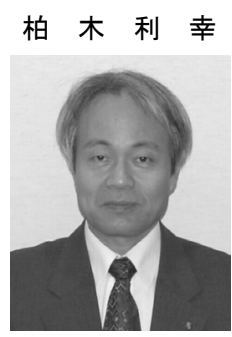

（正員） 1983 年 3 月大阪府立大学工学部電子 工学科卒業, 同年 4 月徳島県庁入庁, 工業試験 場 (現, 徳島県立工業技術センター) 配属。2000 年 9 月徳島大学大学院工学研究科後期博士課 程修了。カラー画像処理, 外観検査の自動化に 関する研究に従事。工学博士。

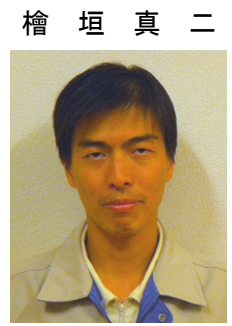

（非会員）1996 年 3 月国立佐賀大学電子工学科 卒業。2001 年 10 月浜松メトリックス（株）入 社。光学フィルム欠陷検查装置, 形状 /外観検 査装置，基板外観検査装置等におけるシステム 設計，電気設計，機械設計，画像処理に従事。

宮 脇 俊 幸

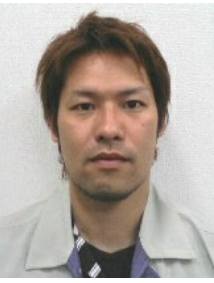

大 恵 俊一郎

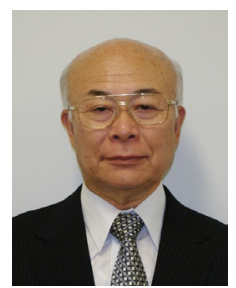

（正員） 1968 年 3 月徳島大学工学部電気工学科 卒業。1970 年 3 月同大学大学院工学研究科修 士課程修了。同年 4 月同大学工学部助手, 講師, 助教授, 教授を経て 2009 年 3 月同大学定年退 職, 2009 年 4 月より四国大学経営情報学部教授。 時系列解析, コンピュータビジョンに関する研 究に従事, 工学博士, 電子情報通信学会, 計測 自動制御学会, 画像電子学会, 日本リモートセ ンシング学会の会員。 